\title{
Experimental Studies of the Effect of Electrolyte Strength, Voltage and Time on the Production of Brown's (HHO) Gas Using Oxyhydrogen Generator
}

\author{
Samuel Pamford Kojo Essuman*, Andrew Nyamful, Vincent Agbodemegbe, Seth Kofi Debrah \\ Department of Nuclear Engineering, Graduate School of Nuclear and Allied Sciences, University of Ghana, Accra, Ghana \\ Email: *akiola.060286@gmail.com
}

\begin{abstract}
How to cite this paper: Essuman, S.P.K., Nyamful, A., Agbodemegbe, V. and Debrah, S.K. (2019) Experimental Studies of the Effect of Electrolyte Strength, Voltage and Time on the Production of Brown's (HHO) Gas Using Oxyhydrogen Generator. Open Journal of Energy Efficiency, 8, 64-80.

https://doi.org/10.4236/ojee.2019.82005
\end{abstract}

Received: March 24, 2019

Accepted: June 24, 2019

Published: June 27, 2019

Copyright $\odot 2019$ by author(s) and Scientific Research Publishing Inc. This work is licensed under the Creative Commons Attribution International License (CC BY 4.0).

http://creativecommons.org/licenses/by/4.0/

\section{(c) (i) Open Access}

\begin{abstract}
A great challenge in water electrolysis is how to optimize the major factors that influence the production of hydrogen gas. Over the past years, different methods have been used to produce hydrogen gas from carbon-base fossil fuels but these methods have been proven to be environmentally unfriendly due to the enormous release of greenhouse gases associated with their use. In this work, an experimental study was carried out to evaluate the effect of electrolyte strength, voltage and time on the volume of $\mathrm{HHO}$ gas produced using a design built $\mathrm{HHO}$ gas generator. The generator was constructed from Stainless Steel $316 \mathrm{~L}$ plates made of 3 anodes, 3 cathodes, and 20 neutral plates. During the study, the strengths of $\mathrm{KOH}, \mathrm{NaOH}$, and $\mathrm{NaHCO}_{3}$ was prepared within the range of $0.010 \mathrm{M}-0.030 \mathrm{M}$. The prepared strengths for each catalyst were then varied across voltage range of $9 \mathrm{~V}$ to $13 \mathrm{~V}$ for 50 seconds. The experimental results obtained showed that, increasing electrolyte strength, voltage and time proportionally increased the yield of HHO gas. An optimal yield rate of $2.27 \mathrm{~cm}^{3} / \mathrm{s}$ of HHO gas was obtained when the generator was run at $13 \mathrm{~V}$ using $0.025 \mathrm{M} \mathrm{KOH}$. In addition, other factors studied including electrode surface morphology, plate's configuration, and temperature also showed improvement in yield of HHO gas by $41.85 \%, 69.74 \%$, and $71.96 \%$ respectively.
\end{abstract}

\section{Keywords}

Oxyhydrogen (HHO) Gas, HHO Gas Generator, Water Electrolysis, Rectifier, Catalyst, Neutral Plate, Bubbler 


\section{Introduction}

Fossil fuels are a versatile and vital energy source which human productive lives are largely dependent on for commodities, transportation, and energy production. The discovery of fossil fuels has injected centuries of ingenious effort into perfecting Internal Combustion Engine (ICE) fueled by gasoline and diesel [1]. Research and development (R\&D) conducted over recent decades has shown that the electric power sector and transportation sector account for $82 \%$ and $95 \%$ respectively of all fossil fuel consumed in the world. This makes fossil fuel the highest consumed source of energy [2]. Despite the usefulness of these fuels, studies have further revealed that the continuous burning of these fossil fuels (coal, oil, and gas) release enormous amount of pollutants (radioactivity, heavy metals, and ashes) and greenhouse gases $\left(\mathrm{CO}, \mathrm{CO}_{2}, \mathrm{SO}_{\mathrm{x}}\right.$, and $\left.\mathrm{NO}_{\mathrm{x}}\right)$ into the environment causing global warming and other related human diseases [3] [4]. Scientists are therefore, investigating new developments in hydrogen-energy technology for a sustainable future [5] [6] [7]. Literature review undertaken on the uses of hydrogen-rich (HHO) gas from 2012 to 2017 showed limited research into the reduction in the concentrations of $\mathrm{SO}_{2}, \mathrm{NO}_{\mathrm{x}}, \mathrm{CO}$, and THCs emitted from the combustion chamber of ICEs using hydrogen-rich (HHO) gas/gasoline/air mixture. However, the evaluation of the major factors that influence the production of this hydrogen-rich gas has not been studied extensively within the period reviewed.

The development of a hydrogen generator for hydrogen gas production was investigated by Arinola B. Ajayi and Olayiwola O. Akerele in 2013 [8]. Their result showed an increase in the volume of HHO gas produced (27 liters) when a current of 60 amperes was passed through the electrolytic solution for $30 \mathrm{mi}$ nutes. A similar work done by Munther Issa Kandah in 2014 [9] supported this conclusion. A. L. Yuvaraj and D. Santhanaraj, 2014 [10]; Noor Alam and K. M. Pandey in 2017 [11] further did a systematic study on the electrolytic production of hydrogen gas using graphite as electrode. Their results showed a significant effect on the production of hydrogen gas when the reaction parameters such as the electrolyte concentration of $\mathrm{KOH}$, applied voltage, and current was increased. Ibrahim Dincer and Canan Acar in 2013 [12] also did a comparative assessment of hydrogen production methods from renewable and non-renewable sources. The study was aimed to compare the performances of hydrogen production methods and assess their economic, social and environmental impacts. The methods considered in their study was steam reforming, coal gasification, water electrolysis, biomass gasification, thermochemical water splitting, and high temperature electrolysis. Their results indicated that thermochemical water splitting using $\mathrm{CueCl}$ and SeI cycles was more environmentally benign than the other traditional methods in terms of emissions.

Similarly, the evaluation of the efficiency improvement for electricity generation by combining HHO gas, coal, and oil in a boiler was undertaken by Chia-Nan Wang et al., in 2017 [13]. They established that combining the HHO gas with the coal caused an increase in the efficiency of electricity generation with a positive 
reduction in the concentration of pollutants emitted into the environment. The present study, therefore, seeks to investigate the effects of 5 different strengths of 3 selected catalysts $\left(\mathrm{KOH}, \mathrm{NaOH}\right.$, and $\left.\mathrm{NaHCO}_{3}\right)$, voltage and time on the yield of $\mathrm{HHO}$ gas produced using an $\mathrm{HHO}$ gas generator. The research also evaluates the influence of electrode surface morphology, temperature and neutral plate's configuration presented in other works reviewed.

\subsection{Conventional Methods of Hydrogen Production}

This section outlines some of the traditionally accepted methods used in producing hydrogen gas. The section also shares light on the basic principles underpinning the subject of discussion in this study.

\subsubsection{Steam Reforming}

Steam reforming is one of the most widespread and least expensive process for hydrogen production. About $90 \%$ of all hydrogen used in the world are produced via this method [14]. This is attributed to the high efficiency, low operational and production cost associated with this technology. The most frequently used raw materials in steam reforming are natural gas and light hydrocarbons. Hydrogen gas produced using this method is done in two major stages. In the first stage, the raw material is fed into steam at operating temperature and pressure between $500^{\circ} \mathrm{C}-900^{\circ} \mathrm{C}$ and $0.3-2.5 \mathrm{MPa}$ respectively in a tube reactor filled with nickel oxide [15]. Identified with the syngas $\left(\mathrm{H}_{2}+\mathrm{CO}\right)$ produced during the catalytic process is $\mathrm{CO}_{2}$. The reaction products $\left(\mathrm{H}_{2}+\mathrm{CO}+\mathrm{CO}_{2}\right)$ produced are then channeled through a boiler to produce steam. The steam is then condensed and cooled to a temperature of $360^{\circ} \mathrm{C}$ using an auxiliary condenser. In the second stage, the cooled gas is fed into converters, where carbon monoxide is converted by means of steam into carbon with some amount of carbonic gas which is removed through the process by a reversible exothermic reaction. The chemical reactions associated with this process are shown below. Currently, the efficiency of steam reforming is estimated to be $85 \%$ [15].

$$
\begin{gathered}
\mathrm{CH}_{4}+\mathrm{H}_{2} \mathrm{O}(\mathrm{g}) \rightarrow \mathrm{CO}+3 \mathrm{H}_{2} \text { endothermic } \\
\mathrm{CH}_{4}+2 \mathrm{H}_{2} \mathrm{O}(\mathrm{g}) \rightarrow \mathrm{CO}_{2}+4 \mathrm{H}_{2} \text { endothermic } \\
\mathrm{CO}+\mathrm{H}_{2} \mathrm{O}(\mathrm{g}) \rightarrow \mathrm{CO}_{2}+\mathrm{H}_{2} \text { exothermic } \\
\mathrm{CO}_{2}+\mathrm{H}_{2} \leftrightarrow \mathrm{CO}+\mathrm{H}_{2} \mathrm{O} \text { exothermic }
\end{gathered}
$$

\subsubsection{Partial Oxidation}

This is a non-catalytic process, in which the raw material fed into the production process is gasified in the presence of oxygen ((5), (6)) and steam (7) at temperatures between $1300^{\circ} \mathrm{C}-1500^{\circ} \mathrm{C}$ and pressures of $3-8 \mathrm{MPa}$. Here, the carbon monoxide produced during the process is converted to hydrogen gas and carbon dioxide using steam. This reaction contributes to the maintenance of the equilibrium between the individual reaction products with an established efficiency between $60 \%-75 \%$ [15]. 


$$
\begin{gathered}
\mathrm{CH}_{4}+\mathrm{O}_{2} \rightarrow \mathrm{CO}+2 \mathrm{H}_{2} \text { exothermic } \\
\mathrm{CH}_{4}+2 \mathrm{O}_{2} \rightarrow \mathrm{CO}_{2}+2 \mathrm{H}_{2} \mathrm{O} \text { exothermic } \\
\mathrm{CH}_{4}+\mathrm{H}_{2} \mathrm{O} \rightarrow \mathrm{CO}+3 \mathrm{H}_{2} \text { endothermic }
\end{gathered}
$$

\subsubsection{Autothermal Reforming}

In autothermal reforming, steam is added to the gasified raw material and oxygen via a process called the Fischer-Tropsch synthesis (Holladay et al., 2009). In this reaction, the commonly used catalyst is Nickel-based catalysts. The efficiency of autothermal reforming of methane ((8), (9)) is between $60 \%-75 \%$ slightly lower than that of steam reforming [15].

$$
\begin{aligned}
\mathrm{C}_{m} \mathrm{H}_{n}+\frac{1}{2} m \mathrm{H}_{2} \mathrm{O}+\frac{1}{4} m \mathrm{O}_{2} & \rightarrow m \mathrm{CO}+\left(\frac{1}{2} m+\frac{1}{2} n\right) \mathrm{H}_{2} \\
\mathrm{CH}_{4}+\mathrm{H}_{2} \mathrm{O}+\mathrm{O}_{2} & \rightarrow 3 \mathrm{CO}+7 \mathrm{H}_{2}
\end{aligned}
$$

\subsubsection{Water-Gas Shift}

In Water-gas shift reaction, carbon monoxide is converted to carbon dioxide and hydrogen using steam at temperatures between $400^{\circ} \mathrm{C}-500^{\circ} \mathrm{C}$ in the presence of chrome oxide and iron oxide $\left(\mathrm{Cr}_{2} \mathrm{O}_{3}, \mathrm{Fe}_{2} \mathrm{O}_{3}\right)$ as indicated in (10).

$$
\mathrm{CO}+\mathrm{H}_{2} \mathrm{O} \rightarrow \mathrm{CO}_{2}+\mathrm{H}_{2} \text { exothermic }
$$

The water-gas shift process also goes through two important successive steps. The first step involves the conversion of $90 \%$ of carbon monoxide in a reactor conditioned at temperatures between $350^{\circ} \mathrm{C}-370^{\circ} \mathrm{C}$. In the second step, the remaining carbon monoxide is removed through catalytic methanation or purification. The methanation reactor transforms the residual carbon monoxide (11) or carbon dioxide (12) into methane, thus lowering its concentration [15].

$$
\begin{aligned}
\mathrm{CO}+3 \mathrm{H}_{2} & \rightarrow \mathrm{CH}_{4}+\mathrm{H}_{2} \mathrm{O} \\
\mathrm{CO}_{2}+4 \mathrm{H}_{2} & \rightarrow \mathrm{CH}_{4}+2 \mathrm{H}_{2} \mathrm{O}
\end{aligned}
$$

However, at higher temperatures, the equilibrium of the reaction shifts to the left resulting in the complete transformation of carbon monoxide to hydrogen as shown in Equation (13).

$$
\mathrm{CO}_{2}+\mathrm{H}_{2} \rightarrow \mathrm{CO}+\mathrm{H}_{2} \mathrm{O}
$$

\subsubsection{Pyrolysis and Co-Pyrolysis}

In pyrolysis and co-pyrolysis, raw organic materials are heated and degasified in vacuo at pressures and temperatures between $0.1-0.5 \mathrm{MPa}$ and $500^{\circ} \mathrm{C}-900^{\circ} \mathrm{C}$ respectively [16]. Here, the process is made to occur without oxygen and air to prevent the formation of dioxins [15]. As a result, this process offers significantly lower emissions. The chemical reaction for pyrolysis and co-pyrolysis are generally described using Equation (14). Currently, the application of co-pyrolysis of organic wastes has gain much industrial research and development since the process helps to limit and lightens the burden of wastes in waste disposal [17].

$$
\text { Organic material }+ \text { heat } \rightarrow \mathrm{H}_{2}+\mathrm{CO}+\mathrm{CH}_{4}+\text { other products }
$$




\subsubsection{Alkaline Electrolyzers}

Alkaline electrolyzers are classified as one of the most mature electrolyzer technology available at the world market [18]. Their design consists of anode and cathode electrodes made of steel and nickel-plated steel respectively. The electrolytes used in this technology are aqueous solutions of either potassium hydroxide $(\mathrm{KOH})$ or sodium hydroxide $(\mathrm{NaOH})$. The anode and cathode electrodes are further separated from each other by a semipermeable membrane all submerged in the electrolyte. During operations of a typical alkaline electrolyzer, direct current is passed through the cell to decompose water into hydrogen gas at the cathode and oxygen gas at the anode. The half-anodic and cathodic reactions as well as the net reaction are shown in Equations (15), (16), (17), and (18).

$$
\begin{gathered}
4 \mathrm{H}_{2} \mathrm{O}_{(\mathrm{l})}+4 \mathrm{e}^{-} \rightarrow 2 \mathrm{H}_{2(\mathrm{~g})}+4 \mathrm{OH}^{-}{ }_{(\mathrm{aq})} \\
2 \mathrm{H}_{2} \mathrm{O}_{(1)} \rightarrow \mathrm{O}_{2(\mathrm{~g})}+4 \mathrm{H}^{+}{ }_{(\mathrm{aq})}+4 \mathrm{e}^{-} \\
4 \mathrm{OH}^{-}{ }_{(\mathrm{aq})}+4 \mathrm{H}^{+}{ }_{(\mathrm{aq})} \rightarrow 4 \mathrm{H}_{2} \mathrm{O}_{(\mathrm{l})} \\
2 \mathrm{H}_{2} \mathrm{O}_{(\mathrm{l})} \rightarrow 2 \mathrm{H}_{2(\mathrm{~g})}+\mathrm{O}_{2(\mathrm{~g})}
\end{gathered}
$$

\subsubsection{Polymer Electrolyzers}

Proton exchange membrane (PEM) was produced as an alternative technology to conventional alkaline water electrolyzers. Studies have shown that, Proton exchange membrane technologies offers several advantages over traditional alkaline technology. These include their compact design, higher production rates, and energy efficiency [19]. PEM cells consists primarily of anode and cathode electrodes that are bonded together. These electrodes are composite of electrocatalytic particles and electrolyte polymer. Equations (19), (20) and (21) show the reactions that takes place in a PEM cell.

$$
\begin{aligned}
& \text { Anodic reaction: } 2 \mathrm{H}_{2} \mathrm{O}_{(\mathrm{l})} \rightarrow \mathrm{O}_{2(\mathrm{~g})}+4 \mathrm{H}^{+}{ }_{(\mathrm{aq})}+4 \mathrm{e}^{-} \\
& \text {Cathodic reaction: } 4 \mathrm{H}^{+}{ }_{(\text {aq })}+4 \mathrm{e}^{-}{ }_{(\text {aq })} \rightarrow 2 \mathrm{H}_{2(\mathrm{~g})} \\
& \text { Overall reaction: } 2 \mathrm{H}_{2} \mathrm{O}_{(\mathrm{l})} \rightarrow 2 \mathrm{H}_{2(\mathrm{~g})}+\mathrm{O}_{2(\mathrm{~g})}
\end{aligned}
$$

\subsubsection{Solid Oxide Electrolyzers}

These type of electrolyzers use a solid ceramic material as their main electrolyte. The electrolyte is designed and process to selectively transmit negatively charged oxygen ions at elevated temperatures between $500^{\circ} \mathrm{C}-800^{\circ} \mathrm{C}$ [20]. At the cathode, water combines with electrons from the external circuit to form hydrogen gas and negatively charged oxygen ions. The oxygen ions diffuse through the membrane and react at the anode to form oxygen gas. This reaction gives up electrons to the external circuit which is subsequently measured using ammeter. The half anodic, cathodic and net reactions that take place in solid oxide electrolyzers are depicted below.

$$
\text { Anodic reaction: } \mathrm{O}^{2-}(\mathrm{aq}) \rightarrow \frac{1}{2} \mathrm{O}_{2}(\mathrm{~g})+2 \mathrm{e}^{-}(\mathrm{aq})
$$


Cathodic reaction: $\mathrm{H}_{2} \mathrm{O}(\mathrm{l})+2 \mathrm{e}^{-}(\mathrm{aq}) \rightarrow 2 \mathrm{H}_{2}(\mathrm{~g})+\mathrm{O}^{2-}(\mathrm{aq})$

Overall reaction: $\mathrm{H}_{2} \mathrm{O}(\mathrm{l}) \rightarrow 2 \mathrm{H}_{2}(\mathrm{~g})+\frac{1}{2} \mathrm{O}_{2}(\mathrm{~g})$

\section{Methodology}

\subsection{Materials}

Sodium hydroxide (analytical grade with assay 97\% - 100.5\%), potassium hydroxide (analytical grade with assay $86.1 \%$ ), sodium hydrogen carbonate (analytical grade with assay $99.5 \%$ ), distilled water, $250 \mathrm{~cm}^{3}$ graduated measuring cylinder, spatula, $250 \mathrm{~cm}^{3}$ water bottle, $2000 \mathrm{~cm}^{3}$ volumetric flask, mercury in glass thermometer, and emery sandpaper (of grades 100, 120, 180, 220, and 320).

\subsection{Equipment and Device}

HHO gas generator, rectifier, analytical balance, retort stand.

\subsection{Preparation of Electrolyte Strength}

$1.12 \mathrm{~g}$ of $\mathrm{KOH}$ were placed in a clean $2 \mathrm{~L}$ volumetric flask containing $500 \mathrm{~cm}^{3}$ distilled water. The flask was corked and placed in a sonicator for 10 minutes. The contents in the flask was topped up with distilled water to the $2 \mathrm{~L}$ meniscus mark to obtain $0.01 \mathrm{M} \mathrm{KOH}$. The flask was labeled $\mathrm{V}_{1}$ and was sonicated for additional 5 minutes to ensure homogeneity. The process was repeated using 2.24 $\mathrm{g}, 3.36 \mathrm{~g}, 4.48 \mathrm{~g}$, and $5.60 \mathrm{~g}$ of $\mathrm{KOH}$ to obtain $0.015 \mathrm{M}, 0.020 \mathrm{M}, 0.025 \mathrm{M}$, and $0.030 \mathrm{M}$ respectively. Similar strengths were prepared using $\mathrm{NaOH}$ and $\mathrm{NaHCO}_{3}$ as shown in Table 3.

\subsection{Description of Experimental Setup}

Figure 1 shows the experimental set-up used to produce the HHO gas. The unit consisted of an HHO gas generator, a reservoir tank, bubbler, and a rectifier. The generator was made from 26 square plates of stainless steel sheet (thickness 20 gauge); comprising of 3 cathode plates, 3 anode plates and 20 neutral plates each of surface area $100 \mathrm{~cm}^{2}$. To reduce excessive bubble attachment, a crosshatch pattern was engraved on the surface of the electrodes.

The end plates of the generator were made of high tensile strength material to resist high pressures and operating temperatures. The generator was designed so that the voltage between two successive plates was maintained at 2.6 volts. This was achieved by placing 4 neutral plates between each pair of anode and cathode plate. Table 1 shows the technical specifications of the built generator. As shown in Figure 1, the plates was positioned parallel and spaced with 25 EPDM gaskets of thickness $1.10 \mathrm{~mm}$. Each plate was further equipped with two circular equalization holes (diameter $30 \mathrm{~mm}$ ) spaced at $5 \mathrm{~cm}$ from their respective centers. The equalization holes was created to allow for passage of electrolyte and $\mathrm{HHO}$ gas. In addition, a reservoir tank was placed above the generator to supply the entire unit with electrolyte solution. The $\mathrm{HHO}$ gas produced inside the generator 
Table 1. Specification of HHO gas generator used.

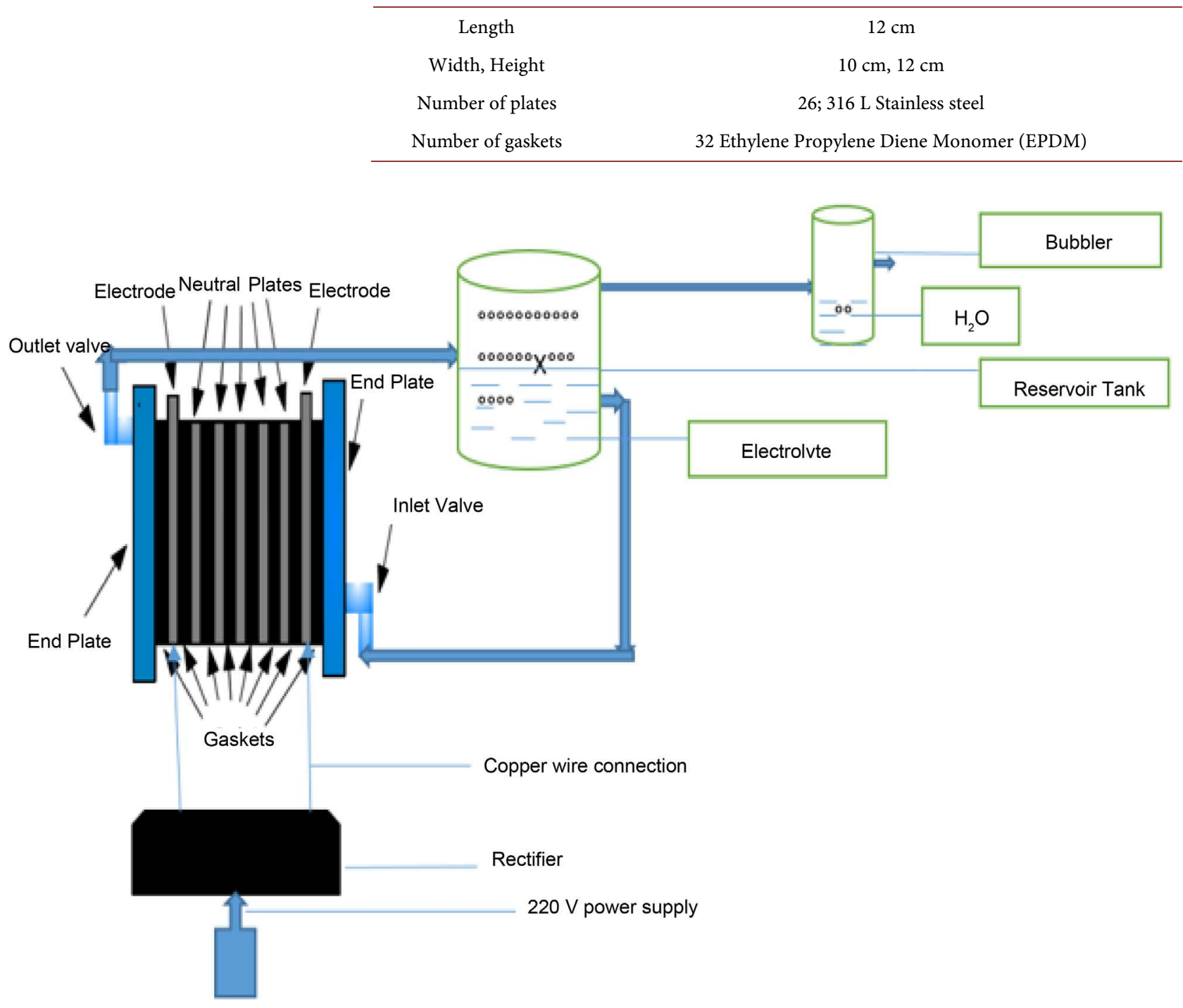

Figure 1. The HHO gas generator unit.

plates was channeled back into the reservoir tank via a 0.5 inch pipe hose. To safeguard the integrity of the system, the reservoir tank was connected to a bubbler. The main function of the bubbler was to condense the water vapor that was produced with the HHO gas during the experiment and to serve as a safety device. Finally, to supply current to the unit, the terminals of the HHO gas generator was connected to a rectifier by using two insulated copper wires following the methods used by (Meyer and Stanely, 1986; Ammar A. Al-Rousan, 2010; and Sa'ed A Musmar, and Ammar A. Al-Al-Rousan, 2011).

\subsection{Experimental Tests}

\subsubsection{Investigating the Effect of Electrolyte Strength, Voltage and} Time on Volume of HHO Gas Produced

After a functionality test of the $\mathrm{HHO}$ gas generating unit, the plates of the gene- 
rator was filled with $0.010 \mathrm{M}$ solution of $\mathrm{KOH}$ through the inlet of the tank to the X-mark as shown in Figure 1. The rectifier with specification described in Table 2 was switched on and the voltage was adjusted to $9 \mathrm{~V}$. The experiment was run for 50 seconds and the volume of HHO gas that flowed from the tank into the bubbler ( $1 / 2$ filled with water) was measured according to section 2.3.2. With the same $0.010 \mathrm{M} \mathrm{KOH}$ solution contained within the generator plates, the experiment was repeated for four other trials at $10 \mathrm{~V}, 11 \mathrm{~V}, 12 \mathrm{~V}$, and $13 \mathrm{~V}$ and the volumes of HHO gas produced were accordingly measured. The entire procedure was further repeated for four other strengths of $\mathrm{KOH}$ as well as those prepared for $\mathrm{NaOH}$ and $\mathrm{NaHCO}_{3}$ in Table 3 following the methods used by (A. L. Yuvaraj and D. Santhanaraj, 2012; Noor Alam and K. M. Pandey, 2017; Mohammad Nazry Bin Rosley et al., 2015).

\subsubsection{Volumetric Measurement of Produced HHO Gas}

Figure 2 shows the set-up used in measuring the volume of the HHO gas

Table 2. Specification of rectifier used.

\begin{tabular}{cc}
\hline Length & $20 \mathrm{~cm}$ \\
Width, Height & $10 \mathrm{~cm}, 14 \mathrm{~cm}$ \\
Rated voltage & $0 \mathrm{~V}-16 \mathrm{~V}$ \\
Rated current & $0 \mathrm{~A}-13 \mathrm{~A}$ \\
Incorporated safety device & Breaker \\
\hline
\end{tabular}

Table 3. Catalyst strength.

\begin{tabular}{cccc}
\hline \multirow{2}{*}{ Strength $\left(\mathrm{mol} / \mathrm{dm}^{3}\right)$} & $\mathrm{NaOH}$ & $\mathrm{KOH}$ & $\mathrm{NaHCO}_{3}$ \\
\cline { 2 - 4 } 0.010 & 0.8 & 1.12 & 1.68 \\
0.015 & 1.6 & 2.24 & 3.36 \\
0.020 & 2.4 & 3.36 & 5.04 \\
0.025 & 3.2 & 4.48 & 6.72 \\
\hline 0.030 & 4.0 & 5.60 & 8.40 \\
\hline
\end{tabular}

Figure 2. Setup for HHO gas volume measurement. 
produced using $\mathrm{KOH}, \mathrm{NaOH}$, and $\mathrm{NaHCO}_{3}$ as catalyst. The volume of gas produced during the tests was measured using the method of water displacement. As outlined in section 2.3.1, as the amount of HHO gas entering the bubbler under concentration gradient from the tank increased, the gas was observed to exert a downward pressure which forced out the water contained inside the bubbler into a $250 \mathrm{~cm}^{3}$ graduated cylinder. The volume of water displaced was then estimated to be equal to the volume of $\mathrm{HHO}$ gas produced.

\subsubsection{Investigating the Variation of System Temperature with Progressive Production of HHO Gas}

In establishing how the temperature of the system varied during the entire experiment, the reservoir tank in Figure 1 was equipped with mercury in glass thermometer. The rectifier was adjusted to $13 \mathrm{~V}$ and the HHO generator was operated using $2 \mathrm{~L}$ solution of $0.030 \mathrm{M} \mathrm{KOH}$ for 5 minutes. The temperature change that occurred within the tank was read on the thermometric scale and recorded every minute for 5 minutes. The corresponding volume of $\mathrm{HHO}$ gas produced in each period was simultaneously measured as described in Section 2.3.2.

\subsubsection{Investigating the Influence of Neutral Plate's Configurations on Volume of HHO Gas Produced}

In this experiment, the generator was arranged into three different configurations; $3 \mathrm{C} 3 \mathrm{~A} 20 \mathrm{~N}, 3 \mathrm{C} 3 \mathrm{~A} 16 \mathrm{~N}$, and $3 \mathrm{C} 3 \mathrm{~A} 12 \mathrm{~N}$. Each of this configuration was operated for 50 s by filling the plates of the generator with $2 \mathrm{~L}$ of $0.030 \mathrm{M} \mathrm{KOH}$ at a constant potential of $13 \mathrm{~V}$. The volume of $\mathrm{HHO}$ gas produced using each configuration was then measured as described in Section 2.3.2.

\subsubsection{Investigating the Influence of Electrode Surface Morphology on Volume of HHO Gas Produced}

In determining the effect of surface morphology of the electrode plates used in the experiment on the volume of $\mathrm{HHO}$ gas produced, the plates of the generator (with configuration $3 \mathrm{C} 3 \mathrm{~A} 20 \mathrm{~N}$ ) was first dismantled, rinsed, cleaned and sun-dried for 30 minutes. After the drying activity, a cross-hatch pattern was engraved on the surface of each plate using emery sand paper grade 100. The engraved plates was then arranged and fixed into the generating unit and run for 50 seconds using $2 \mathrm{~L}$ of $0.030 \mathrm{M} \mathrm{KOH}$ at a constant potential of $13 \mathrm{~V}$. The entire procedure was repeated for 4 other trials but this time varying the electrode plate's surface using grades 120,180, 220 and 320. The respective volumes of $\mathrm{HHO}$ gas produced in each trial was then measured as described earlier.

\section{Results and Discussion}

\subsection{Results}

Results of the investigations conducted in the present work are presented and discussed in this session.

\subsubsection{Investigating the Effect of Time on the Experimental Reaction}

In this study, various strengths of $\mathrm{KOH}, \mathrm{NaOH}$, and $\mathrm{NaHCO}_{3}$ was varied at $13 \mathrm{~V}$ 
using an adjustable rectifier for 50 seconds. The values recorded in Table 4 shows that, the yield of $\mathrm{HHO}$ gas increased with increasing time.

\subsubsection{Studying the Effect of Electrolyte Strength on Oxyhydrogen Gas Produced}

In this experiment, prepared strengths of $\mathrm{KOH}, \mathrm{NaOH}$, and $\mathrm{NaHCO}_{3}$ was varied using a constant potential of $13 \mathrm{~V}$ and period of 50s to evaluate the influence of concentration on the yield of HHO gas. The values recorded in Table 5 shows that, increasing the strengths of the selected catalyst increased the yield of $\mathrm{HHO}$ gas produced experimentally.

3.1.3. Evaluating the Effect of Voltage on Yield of Oxyhydrogen Produced On studying how potential difference used in the experiment influenced the volume of HHO produced, a voltage range of $9 \mathrm{~V}-13 \mathrm{~V}$ was varied using $0.05 \mathrm{M}$ solution each of $\mathrm{KOH}, \mathrm{NaOH}$, and $\mathrm{NaHCO}_{3}$. Table 6 shows that, increasing voltage increased the $\mathrm{HHO}$ gas yield recorded.

Table 4. Experimental values obtained when the effect of time on volume of HHO gas produced was studied.

\begin{tabular}{cccc}
\hline \multirow{2}{*}{ Time $(\mathrm{s})$} & \multicolumn{3}{c}{ Volume of $\mathrm{HHO}$ gas produced at } \\
\cline { 2 - 4 } & $\mathrm{KOH}\left(\mathrm{cm}^{3}\right)$ & $\mathrm{NaOH}\left(\mathrm{cm}^{3}\right)$ & $\mathrm{NaHCO}_{3}\left(\mathrm{~cm}^{3}\right)$ \\
\hline 10 & 31.4 & 28.0 & 15.7 \\
20 & 49.3 & 43.9 & 18.6 \\
30 & 66.0 & 58.1 & 21.0 \\
40 & 82.5 & 73.1 & 23.0 \\
50 & 97.1 & 87.9 & 25.3 \\
\hline
\end{tabular}

Table 5. Yield of HHO gas recorded when electrolyte strength was varied against potential difference of $13 \mathrm{~V}$ for 50 seconds.

\begin{tabular}{cccc}
\hline \multirow{2}{*}{ Strength $(\mathrm{M})$} & \multicolumn{3}{c}{ Volume of HHO gas produced at constant voltage of $13 \mathrm{~V}$} \\
\cline { 2 - 4 } & $\mathrm{KOH}\left(\mathrm{cm}^{3}\right)$ & $\mathrm{NaOH}\left(\mathrm{cm}^{3}\right)$ & $\mathrm{NaHCO}_{3}\left(\mathrm{~cm}^{3}\right)$ \\
\hline 0.010 & 32.8 & 28.0 & 11.8 \\
0.015 & 60.7 & 43.9 & 19.1 \\
0.020 & 60.7 & 61.3 & 22.8 \\
0.025 & 88.8 & 69.8 & 25.4 \\
0.030 & 83.3 & 74.0 & 24.5 \\
\hline
\end{tabular}

Table 6. Results obtained when voltage was varied using $0.05 \mathrm{M}$ strength each electrolyte of $\mathrm{KOH}, \mathrm{NaOH}$, and $\mathrm{NaHCO}_{3}$ for 50 seconds.

\begin{tabular}{cccc}
\hline \multirow{2}{*}{ Voltage $(\mathrm{V})$} & \multicolumn{3}{c}{ Volume of $\mathrm{HHO}$ gas produced at $0.05 \mathrm{M}$ electrolyte strength of $\mathrm{KOH}$} \\
\cline { 2 - 4 } & $\mathrm{KOH}\left(\mathrm{cm}^{3}\right)$ & $\mathrm{NaOH}\left(\mathrm{cm}^{3}\right)$ & $\mathrm{NaHCO}_{3}\left(\mathrm{~cm}^{3}\right)$ \\
\hline 9 & 26.8 & 21.9 & 11.9 \\
10 & 34.8 & 31.6 & 17.7 \\
11 & 59.3 & 56.7 & 19.9 \\
12 & 91.7 & 84.4 & 25.0 \\
13 & 113.5 & 99.3 & 29.0 \\
\hline
\end{tabular}




\subsubsection{Effect of Continuous Production of HHO Gas on Systems Temperature}

The temperature variation resulting from the generation of HHO gas by an HHO gas generator was measured experimentally using a mercury in glass thermometer. Table 7 shows that, increasing the production of HHO gas caused a corresponding increase in temperature value.

\subsubsection{Influence of Neutral Plates on Yield of HHO Gas Produced}

Neutral plates in this experiment was varied to study the effect of number of cells creation on the volume of $\mathrm{HHO}$ gas that could be produce experimentally. In this study, three configurations of the generating unit was made to run on $0.02 \mathrm{M} \mathrm{KOH}$ for 50 seconds. Table 8 shows that, increasing the number of neutral plates in the configuration adopted increased the HHO gas production.

\subsubsection{Studying the Effect of Electrode Surface Roughness on Yield of HHO Gas Produced}

Table 9 gives the emery sand paper grades and the respective volumes of HHO gas that was produced when the electrode surfaces was modified. The results obtained confirm that, increasing the roughness of the electrode surafces progressively increased the volume of $\mathrm{HHO}$ gas produced in the experiment.

\subsection{Discussions}

\subsubsection{Effect of Time on HHO Gas Production}

In order to study the sustainability and stability of the square SS 316L electrodes used in the experiment, the effect of time on the HHO gas evolution reaction was studied under optimized reaction conditions. From the Figure 3, the linear profile of oxyhydrogen production for each catalyst produced over the entire 50 seconds demonstrates that the SS electrode remained stable without any surface destruction throughout the experiment. Similarly, using the rate law of chemical

Table 7. Temperature values measured from the HHO gas generating unit.

\begin{tabular}{cc}
\hline Temperature $\left({ }^{\circ} \mathrm{C}\right)$ & Volume of HHO gas Produced $\left(\mathrm{cm}^{3}\right)$ \\
\hline 32 & 189 \\
35 & 226 \\
39 & 260 \\
40 & 287 \\
44 & 325 \\
\hline
\end{tabular}

Table 8. Volume of HHO gas recorded from variation in number of neutral plates.

\begin{tabular}{ccc}
\hline Generator configuration & Number of Neutral plates $(\mathrm{N})$ & $\begin{array}{c}\text { Volume of HHO gas } \\
\text { Produced }\left(\mathrm{cm}^{3}\right)\end{array}$ \\
\hline 3C3A & 12 & 152 \\
3C3A & 16 & 176 \\
3C3A & 20 & 258 \\
\hline
\end{tabular}


Table 9. Volume of HHO recorded by varying the surface roughness of the SS electrodes using five different emery grade.

\begin{tabular}{cc}
\hline Emery Grade \# & Volume of HHO gas Produced $\left(\mathrm{cm}^{3}\right)$ \\
\hline 100 & 325 \\
120 & 287 \\
180 & 241 \\
220 & 226 \\
320 & 189 \\
\hline
\end{tabular}

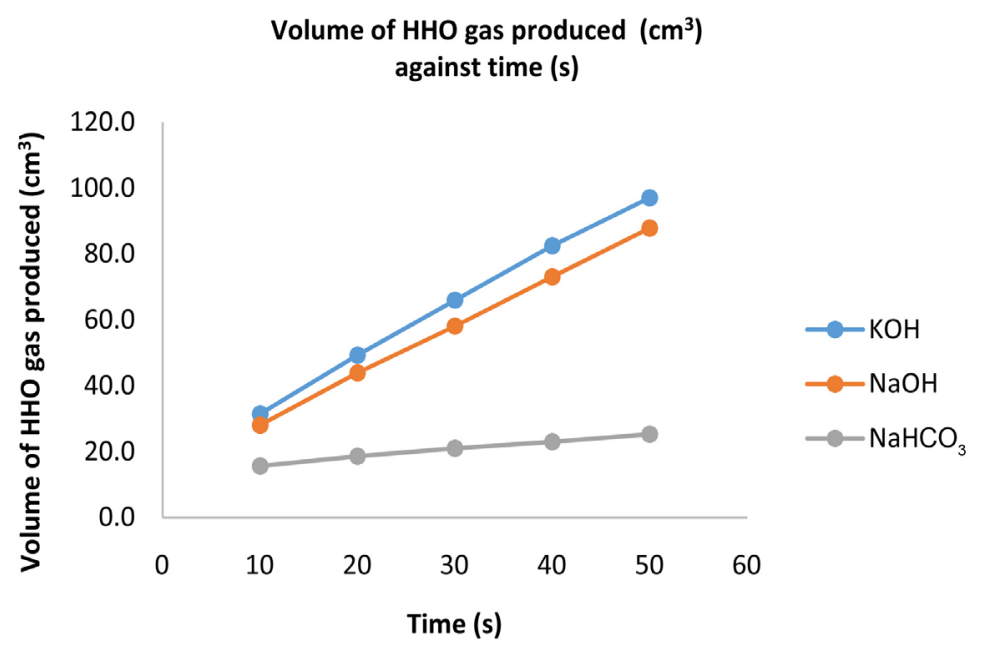

Figure 3. Volume of HHO gas-time profile at constant electrolyte strength and voltage.

reaction, the gradual increase in movement between the molecules of the Hydrogen gas and Oxygen gas produced during the electrolysis process caused an increase in the average kinetic energy of their constituent molecules. This therefore, increased the number of effective molecular collision per unit time resulting in the higher yield of $\mathrm{HHO}$ gas observed. This result also affirms an experimental research done by Noor Alam and K. M. Pandey in 2017.

\subsubsection{Effect of Voltage on HHO Gas Production}

The hydrogen evolution reaction (HER) and the oxygen evolution reaction (OER) in this experiment was studied over flat square SS 316 electrodes at a laboratory temperature of $25^{\circ} \mathrm{C}$ using $0.030 \mathrm{M}$ strengths of $\mathrm{KOH}, \mathrm{NaOH}$, and $\mathrm{NaHCO}_{3}$ respectively. The applied voltage to the system was varied from $9 \mathrm{~V}$ to $13 \mathrm{~V}$. Figure 4 shows that, increasing the potential of the system, increased the volume of HHO gas produced. This can be due to the reason that, increasing the current increased the exchange factor between the electrons and the positively charged hydrogen ions. However, the volume of the HHO gas produced during the study was observed to be higher for $\mathrm{KOH}$ followed by $\mathrm{NaOH}$ and $\mathrm{NaHCO}_{3}$ due to the relative ionisation and conductivity power of the respective catalyst used. 


\section{Voltage flow (V) vs. HHO gas volume}

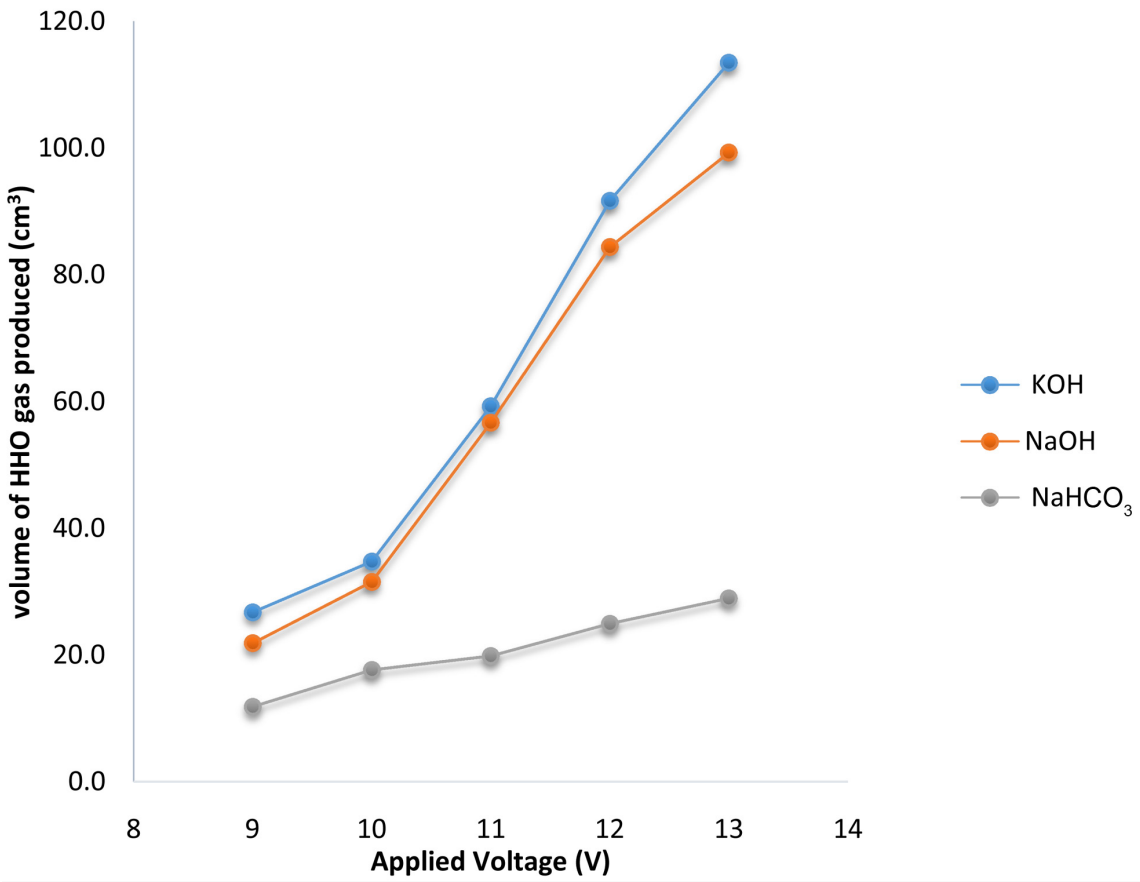

Figure 4. Volume of HHO gas-voltage profile at constant strength and time.

\subsubsection{Effect of Electrolyte Strength on HHO Gas Production}

In establishing the effect of electrolyte strengths on the yield of $\mathrm{HHO}$ gas produced during the experiment, the rectifier connected to the generator was adjusted to a voltage of $13 \mathrm{~V}$. From the study, it was realized that, as the concentration of each electrolyte was increased, the ionic conductivity of the distilled water also increased whilst at the same time the resistance of the overall generator unit was reduced. Figure 5 shows how the yield of the HHO gas production gradually increased with increasing electrolyte concentration. The increase in the volume of HHO gas observed can be attributed to the increase in hydrogen evolution and oxygen evolution due to the greater number of effective ionic collision per unit time. This result supports the experimental outcome obtained by Noor Alam and K. M. Pandey in 2017.

\subsubsection{Effect of Temperature on Volume of HHO Gas Produced}

Figure 6 shows the temperature and volume of HHO gas profile of the experiment undertaken. Temperature is one of the most significant variables in water electrolysis due to the direct relationship it has with the applied potential of the generating system. The timely production of the HHO gas was observed to increase the temperature of the generating unit. This made the generator more efficient and thereby used less energy for the production process. Furthermore, the gradual increase in temperature decreased the rupture potential of the water molecules, increased the ionic conductivity of the electrolyte and the electrical conductivity as well as the surface reaction of the electrodes. This observation could be explained using the mass transfer of the ions that occurred during the 


\section{Variation of volume of HHO gas produced $\left(\mathrm{cm}^{3}\right)$} against strength $(\mathrm{M})$

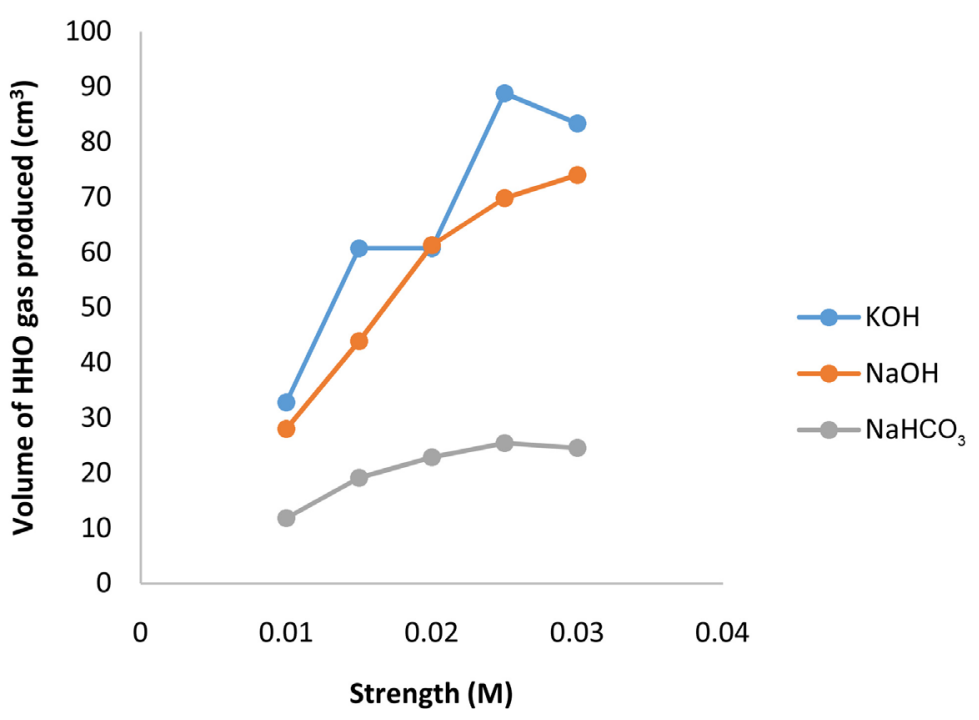

Figure 5. Volume of HHO gas-electrolyte strength profile at constant voltage and time.

\section{Effect of temperature on volume of $\mathrm{HHO}$ gas $\left(\mathrm{cm}^{3}\right)$}

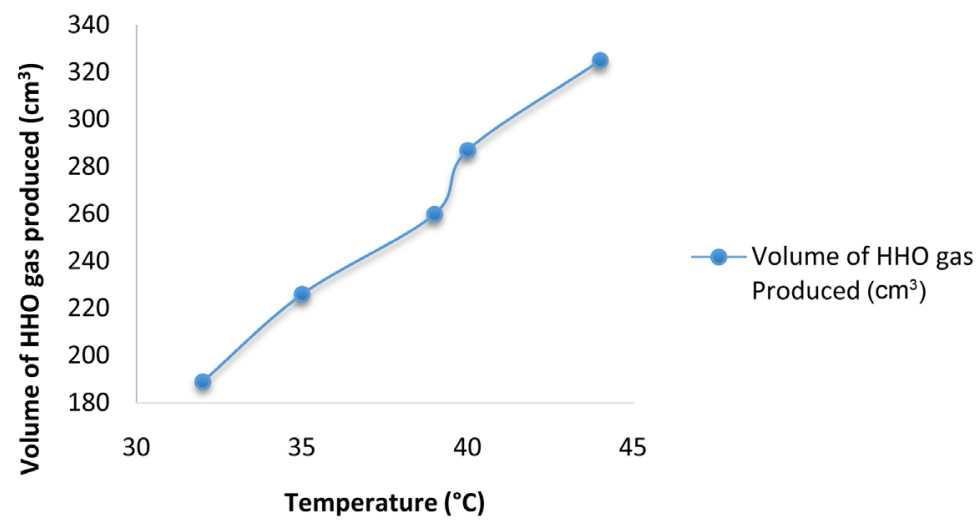

Figure 6. Volume of HHO gas-temperature profile.

electrolysis process. Since an increase in temperature favors the molecular collisions between ions, the high number of molecular collisions was poised to increase the HHO gas yield. This results further conform to Faraday's law which states that "the mass of substance that is deposited, or released in an electrode, is directly proportional to the amount of electric current flowing through the electrolyte".

\subsubsection{Effect of Varying Neutral Plates on Volume of HHO Gas Produced} The graph in Figure 7 shows how the variation of plate's configuration in an $\mathrm{HHO}$ gas generator influenced the volume of $\mathrm{HHO}$ gas that was produced. In the experiment, it was noted that increasing the number of neutral plates between the cathodes and anodes decreased the system potential. The drop in 


\section{Effect of neutral plate variation on volume of $\mathrm{HHO}$ gas $\left(\mathrm{cm}^{3}\right)$}

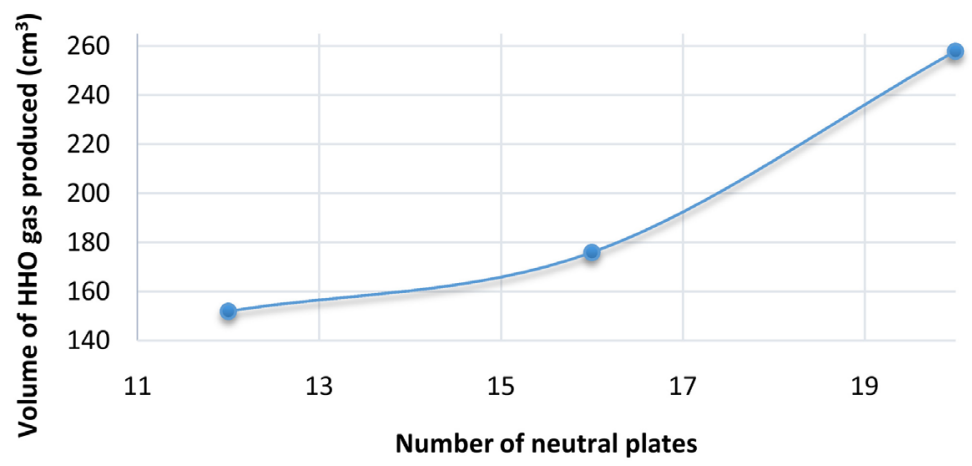

Figure 7. Volume of HHO gas-neutral plates profile.

potential increased the temperature which further enhanced the ionic mobility and the number of effective collisions resulting in the significant volume of the HHO gas observed.

\subsubsection{Effect of Electrode Surface Morphology on Volume of HHO Gas Produced Gas}

The covering of electrode surfaces by hydrogen and oxygen molecules in literature is well known to reduce and increase the ohmic resistance as well as the electrical conductivity in water electrolysis (K. Qian et al. 1998). In this experiment, to eliminate this effect, the surface of electrodes used in electrolytic processes was modified (Munther Issa Kandah, 2014). From Figure 8, increasing the roughness of the electrode plates by engraving cross-hatch patterns on the surface of the plates using emery sand papers was found to increase the volume of HHO gas produced. This observation could be attributed to the fact that, as the surface of the electrode becomes rougher, the plate's area increases and this therefore, reduced the attractive forces between the bubbles and electrode surface leading to the increase in the evolution of $\mathrm{HHO}$ gas witnessed.

\section{Conclusion}

The effect of electrolyte strength, voltage, and time on the volume of $\mathrm{HHO}$ gas produced using a design built $\mathrm{HHO}$ generator was studied. The configuration of the generator was done based on thermodynamic and electrochemical principles of water electrolysis. The study showed that increasing the electrolyte strength, voltage and time increased the volume of $\mathrm{HHO}$ gas produced. The optimal yield rate of HHO gas produced was however observed to be $2.27 \mathrm{~cm}^{3} / \mathrm{s}$ when the generator was run at $13 \mathrm{~V}$ using $0.025 \mathrm{M} \mathrm{KOH}$. In addition, other factors studied including electrode surface morphology, neutral plate's configuration and temperature further showed great enhancement in the production of $\mathrm{HHO}$ gas by $41.85 \%, 69.74 \%$, and $71.96 \%$ respectively. The increment in yield of $\mathrm{HHO}$ gas observed was explained using ohm's law, the mass transfer principle, ionic mobility as well as electrolyte resistance of the generator unit. 
Effect of electrode polishing on Volume of $\mathrm{HHO}$ gas $\left(\mathrm{cm}^{3}\right)$

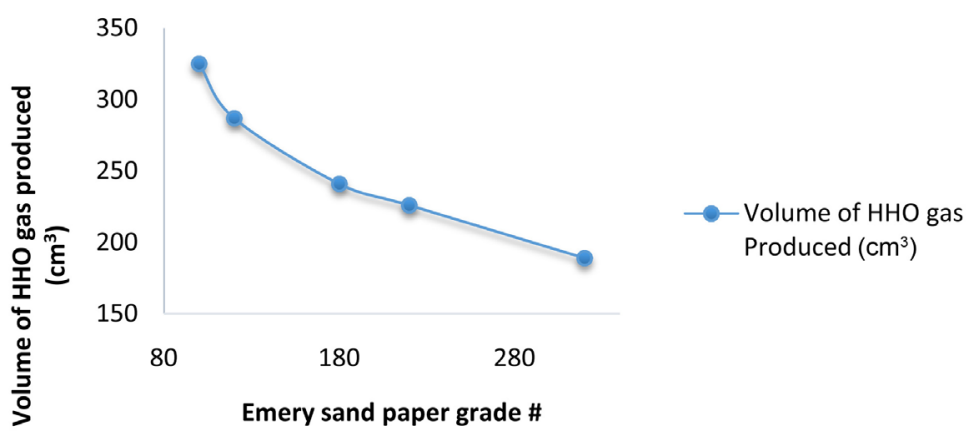

Figure 8. Volume of HHO gas-electrode surface morphology profile.

\section{Recommendation for Future Research}

Electrode material loss is one phenomenon that usually occurs during water electrolysis due to the effect of catalyst concentration. To minimize this effect, the authors of this study finds it imperative to recommend further research work into the development of commercially available electrode materials such as platinum, surgical stainless steel, graphite, EN8 and carbon rods to enhance the technology for HHO gas production.

\section{Acknowledgements}

I would like to acknowledge Miss Catherine Kuamoah, Miss Hephzibah Ewuradjoa Pamford Essuman, Mr. Cephas Hammond and Mr. George Crabbe for their immense support that ensured the successful completion of this study.

\section{Conflicts of Interest}

The authors declare no conflicts of interest regarding the publication of this paper.

\section{References}

[1] Balabel, A. and Zaky, M.S. (2011) Experimental Investigation of Solar-Hydrogen Energy System Performance. International Journal of Hydrogen Energy, 36, 46534663. https://doi.org/10.1016/j.ijhydene.2011.01.040

[2] USEA: U.S. Energy Information Administration (2011) Emissions of Green House Gases Report. http://205.254.135.24/oiaf/1605/ggrpt/carbon.html

[3] Kreuter, W. and Hofmann, H. (2008) Electrolysis: The Important Energy Transformer in a World of Sustainable Energy. International Journal of Hydrogen Ener$g y$, 23, 661-666. https://doi.org/10.1016/S0360-3199(97)00109-2

[4] Tester, J.W., Drake, E.M., Driscoll, M.J., Golay, M.W. and Peters, W.A. (2005) Sustainable Energy: Choosing among Options. MIT Press, Cambridge.

[5] Kesis, G., Zeps, M. and Vanags, M. (2009) Parameters of an Efficient Electrolysis Cell. Latvian Journal of Physics and Technical Sciences, 3, 6-12.

[6] Hubbert, M.K. (1956) Shell Development Company Exploration and Production Research Division. Publication No. 95 Houston Texas.

[7] Meurer, C., Barthels, H., Brocke, W.A., Emonts, B. and Groehn, H.G. (2009) Phoe- 
busan Autonomous Supply System with Renewable Energy: Six Years of Operational Experience and Advanced Concepts. Solar Energy, 67, 131-138. https://doi.org/10.1016/S0038-092X(00)00043-8

[8] Ajayi, A.B. and Akerele, O.O. (2013) Development of Hydrogen Generator for Hydrogen Gas Production. The International Journal of Engineering and Science, 2, 126-130. http://www.theijes.com

[9] Kandah, M.I. (2014) Enhancement of Water Electrolyzer Efficiency. Journal of Energy Technologies and Policy, 4, 1-9. http://www.iiste.org

[10] Yuvaraja, A.L. and Santhanaraj, D. (2014) A Systematic Study on Electrolytic Production of Hydrogen Gas by Using Graphite as Electrode. Materials Research, 17, 83-87. https://doi.org/10.1590/S1516-14392013005000153

[11] Alarm, N. and Pandey, K.M. (2017) Experimental Study of Hydroxyl Gas (HHO) Production with Variation in Current, Voltage and Electrolyte Concentration. IOP Conference Series: Materials Science and Engineering, 225, Article ID: 012197. https://doi.org/10.1088/1757-899X/225/1/012197

[12] Acar, C. and Dincer, I. (2013) Comparative Assessment of Hydrogen Production Methods from Renewable and Non-Renewable Sources. Faculty of Engineering and Applied Science, University of Ontario Institute of Technology, Oshawa.

[13] Wang, C.-N., Chou, M.-T., Hsu, H.-P., Wang, J.-W. and Selvaraj, S. (2017) The Efficiency Improvement by Combining $\mathrm{HHO}$ Gas, Coal and Oil in Boiler for Electricity Generation. Energies, 10, 251. https://doi.org/10.3390/en10020251

[14] Palmová, I. and Schöngut, J. (2004) Outlook of Production and Utilization of Hydrogen. Chemicke Listy, 98, 205-210.

[15] Holladay, J.D., Hu, J., King, D.L. and Wang, Y. (2009) An Overview of Hydrogen Production Technologies. Catalysis Today, 139, 244-260. https://doi.org/10.1016/j.cattod.2008.08.039

[16] Ni, M., Leung, D.Y.C., Leung, M.K.H. and Sumathy, K. (2006) An Overview of Hydrogen Production from Biomass. Fuel Processing Technology, 87, 461-472. https://doi.org/10.1016/j.fuproc.2005.11.003

[17] Bičáková, O. (2001) Co-Pyrolysis of Coal/Organic Wastes Mixtures. Dissertation, Department of Gas, Coke and Air Protection, Faculty of Environmental Technology, Institute of Chemical Technology, Prague.

[18] Kai, Z. and Zhang, D. (2010) Recent Progress in Alkaline Water Electrolysis for Hydrogen Production and Applications. Progress in Energy and Combustion Science, 36, 307-326. https://doi.org/10.1016/j.pecs.2009.11.002

[19] Bard, A.J. and Faulkner, L.R. (2001) Electrochemical Methods: Fundamentals and Applications. 2nd Edition, John Wiley \& Sons, New York.

[20] Lei, B., Samir, B. and Enrico, T. (2014) Steam Electrolysis by Solid Oxide Electrolysis Cells (SOECs) with Proton-Conducting Oxides. Chemical Society Reviews, 43, 8255-8270. https://doi.org/10.1039/C4CS00194J 